\title{
The Influence of Fiscal Policy on Foreign Direct Investment Inflow: A Case Study of Ireland
}

\author{
Adeola A. Adeniyi John Seils \\ International Business Department, Southern New Hampshire University, 2500 North River Road, Manchester, \\ NH 03106-1045
}

\begin{abstract}
The level of influence from fiscal policy on foreign direct investment inflow (FDI) is controversial. This study investigates the relationship between foreign direct investments and corporate tax rates relative to other determinants within the European Union compared to Ireland. In this study, a panel regression analysis was employed to evaluate data from the United Nations Conference on Trade and Development (UNCTAD), World Bank and Organization for Economic Co-operation and Development (OECD) from 1990-2017. The result shows that there is a positive correlation between corporate tax rate, labor force, and foreign direct investment inflow in Ireland. Also, the corporate tax rate, inflation rate and Labor force rate have a significant impact on the FDI inflow in the economy growth of the Ireland. The understanding of the behavior of these factors can provide useful information to the Ireland government and policy makers as they seek to improve foreign direct investment inflow through building more infrastructure, increased market share, education quality and reformation in tax policy to encourage domestic investment and attract new investors to the Nation. The study recommends that firms seek financial gain through corporate tax rates as a leading determinant and aim to identify how corporate tax rates contrast in FDI levels between countries within the EU should acknowledge that other factors that can create a healthy business environment for sustainable growth for both in the investing MNEs and host nations.
\end{abstract}

Keywords: Foreign Direct Investment (FDI), Corporate Tax, Inflation, Labor Force rate, Trade Openness.

DOI: $10.7176 /$ RJFA/12-2-04

Publication date: January $31^{\text {st }} 2021$

\subsection{Introduction}

Multinational Enterprises continue to seek out opportunities to gain an advantage over industry competition. Gaining a competitive advantage can manifest itself through a variety of (Gilleard, 2013) opportunities whether through long-term risk mitigation, product diversification, acquiring new technologies, or entering a new market previously unexposed to the product or service offered by the firm. Many factors are unique to an industry or market. However, the desire to increase shareholder value by the firm is ultimately the driving force that dictates decisions to invest in foreign emerging markets. While many firms seek out opportunity unique to an industry or market, external factors also influence the decision to invest. A country GDP, unemployment rate, educational levels, geographical access to trade and government policy are all locational factors that are not unique to an industry but enhance the attractiveness to invest in an emerging market (Veugelers, 1991).

Firms need to adapt to both the internal and external environment in order to remain competitive. Stagnation and failure to innovate leads to obsolescence. Over the last 30 years, technology presents new opportunities and factors in the global economy that forces firms to identify, adopt and execute new practices in the global market. When there is a shift in the global economy, there are primary, secondary and tertiary effects on the individual economies. For example, if oil-producing countries create a policy agreement for production caps in order to increase the oil prices, transportation costs increase in the global economy. As a result, companies may exercise trade routes that are closer in order to save costs of transportation by seeking geographical locations closer to their market. This, in turn, may cause a migration in production with slightly higher labor but greatly lower transportation costs resulting in decrease for costs absorbed by the firm. When shifts in the global economy occur, the reactionary drive for innovation can increase the interconnected web of foreign markets with developed countries

\section{Understanding the Effects of Policy Factors on Foreign Direct Investment (FDI)}

Policy factors on foreign direct investments are not always unique to a specific industry but act to destabilize the market and forces recognition and adjustments from MNEs. Just as firms are interested in resources and market shares, they also seek out conditions for growth such as a growing GDP, education levels, unemployment rates and fiscal policy. Governments utilize fiscal policy as a tool to support growth, innovation and create an economically friendly business environment to promote growth, innovation and competition (Cassou, 1997). Fiscal policy takes form in a variety of ways, but this paper will focus more on the corporate tax rates adopted by various countries as a means of attracting foreign direct investments to their country.

Arguably, corporate tax rates play a major factor to stimulate existing business and attract investments. For MNEs, countries with low corporate tax rates become tax havens which cause corporations to shift operations to earn greater profits (Krautheim \& Schmidt, 2011). Ideally, businesses pay less in taxes to the government, which 
leaves more money for the firm to reinvest in growth and innovation. In turn, businesses have a larger budget to increase salaries or increase their workforce drawing employment from the host nation population (Mitchell, 2008). This relationship is a mutually beneficial between governments and businesses because businesses reinvest more money to grow or strengthen their business and the local population enjoy greater employment and salary opportunities.

On a larger scale, a country can attract business to operate in their country and increase living conditions that follow lower unemployment levels (Mitchell, 2008). However, low corporate tax rates translate into less capital for the government to provide services to the population such as social welfare programs, a standing military, or infrastructure development. The balance between social support and corporate taxes countries strive to achieve in order to attract foreign direct investments in known as tax harmonization (Neruda, 2008). Corporate tax rates fluctuate according to the health of an economy or global market conditions and may be relative to the rates practiced by surrounding countries. Other factors may compliment or detract from the intended effects of fiscal policy. The attractive nature of lower corporate tax rates may only maintain their appeal when relative to higher corporate tax rates from other surrounding countries. Naturally, tax competition arises between countries in a region such as the European Union. The outlying country with low corporate tax rates forces surrounding countries to decide between more capital to build internally for host nation population or lose valuable foreign direct investments (Mitchell, 2008). The outlier, the country with a relatively low corporate tax rate enjoys the benefits of influx of capital via foreign direct investments which increase employment opportunities and strengthen infrastructure within their borders (Gondor \& Nistor, Fiscal Policy and Foreign Direct Investment: Evidence from some Emerging EU Economies, 2012). The importance of this research is to identify a corporate tax policy that attracts foreign direct investment and fosters a healthy business environment for sustainable growth for host nations. This study is aimed to find answer to the following research question "How does host nation corporate tax rate influence inflow of foreign direct investment in the European Union relative to surrounding regions? How does corporate tax rate effect the inflow of foreign direct investments? How does corporate tax rate effect the inflow of foreign direct investments relative to other factors? Do surrounding regions experience influence of FDI as a result of CTR as well as Ireland?

This particular study is very important because it is designed to fill the literature gap by providing a better understanding about the relationship between foreign direct investments and corporate tax rates relative to other determinants within the European Union to inform policy. In addition to theories relating to location, corporate tax rate may act as a major differentiator that influences the decision of FDI for MNEs. All other factors being equal, how important, and to what degree do MNEs seek out low corporate rates? This research paper attempts to bridge the gap in the field of study by examining the corporate tax rate as a competitive advantage on foreign direct investment inflow in Ireland and other selected nations in European Union. Additionally, we will determine whether corporate tax is a decisive factor that influences multinational firms to invest abroad versus home country.

\subsection{Literature Review}

There is not one single theory that explains the nature of Foreign Direct Investment, hence FDI should be viewed in different theories with combination of factors from a variety of theoretical models (Falth, 2000). FDI is an international investment within the balance of payment accounts. Essentially, it explains a resident entity in one economy seeking to obtain a lasting interest in an enterprise resident in another economy. The theory by Dunning (1997), standard Ownership, Location and Internalization (OLI) approach explains that MNCs engage in FDI when three sets of determining factors simultaneously emerge: Ownership, Location and Internalization advantages (Dunning, 2000). Ownership advantage refers to products or production processes that other firms do not have access to, such as patents, intangible elements like reputation for quality or brand names. Location advantages pertain to the host country's quality of business environment such as low tax rate, low factor prices or customer access, as well as relative low trade barriers or transport costs, which makes FDI more profitable than exporting. Internalization advantages derive from the firm's interest in maintaining its knowledge.

Numerous studies have tried to identify whether taxes are relevant determinants for foreign direct investment (FDI). Diamond \& Mirrlees (1971) concluded that small economies should avoid taxing the income obtained by foreign investors, in order to attract foreign direct investment. The study of Goodspeed et al (2007) showed that the role of the government policies in attracting FDI is by increasing government expenditures such as investment in infrastructures and lowering taxation. Hines (1999) found that a reduced tax burden affects the level of FDI. Gropp (2000) discovers a link between taxation and FDI and suggested that changes in the tax rate have generated a significant impact on investment decisions especially in Organization for Economic Co-operation and Development (OECD) countries. He argued that the low tax rate in Ireland contributed decisively to the country's success in attracting FDI. Gilleard (2013) stated that while many countries, for example the United Kingdom, increasingly try to attract FDI through an attractive fiscal policy such as systematic reduction of the nominal tax rate in order to gain a competitive advantage, other European countries like Austria, Belgium, Denmark, Greece, and Italy manage to attract FDI even with complex and very unattractive fiscal regimes. Desai (2001) studied the 
relationship between the impact of indirect taxes and foreign investment decisions and found indirect tax statistically significantly affects the FDI decisions of United States Multinational firms. Desai (2002) postulated that the allocation of results between different entities of the same group with headquarters in different countries is normally sensitive to differences in the tax rate between countries. Razin \& Sadka (2006) showed the importance of different tax rates among countries in the FDI decision. Other authors studied the relationship between FDI, corporate tax rate and income generated by this tax (Hartman, 1984: Boskin \& Gale,1987; Young, 1988; Slemrod 1990; Swenson, 1994; Cummins \& Hubbard, 1995; Grubert \& Mutti, 2000; Bénassy-Quéré, 2003). In general, these studies concluded that there is a relationship between the tax rate and the level of FDI in the countries analyzed.

However, diverging from the literature above, some studies reveal that the fiscal effect of the tax rate does not affect FDI significantly. Cassou (1997) analyzed the FDI made in the period 1970-1989 in a certain number of countries and concluded that in most cases fiscal policy effect was not statistically significant in the FDI attraction. Like Jun (1994) and Devereux \& Freeman (1995) reached an identical conclusion that taxation does not affect location of FDI. Pain \& Young (1996) studied the FDI attractiveness in Germany, United Kingdom and other 11 countries during the period 1977-1992. They found that fiscal effects were not statistically significant in FDI decision. The study of Bénassy-Quéré, Fontagné and Lahreche (2005) supported the discovery through the non-existence of a linear relationship between corporate tax rate and FDI conclusion.

Furthermore, foreign direct investment (FDI) decisions include country's level of risk, labor costs, market size, level of development of the private sector and corruption levels (Lucas, 1993; Alan \& Estrin, 2000) while market size, the country's proximity to the source of investment, state policies on receiving investment are some factors of attraction for foreign investment. The empirical studies of Bevan \& Estrin, 2000; Carstensen \& Toubal, 2004; Janicki \& Wunnava, 2004, Lankes \& Venables, 1996; Lim, 2001 and Singh \& Jun 1996 agreed that attractiveness factors are the most important explanatory variables of foreign investment decisions but that some researchers believe that the policies of the host country are also factors to bear in mind in FDI decisions. Considering investment decisions like labor costs, the tax burden, infrastructure, interest rate and commercial policies, a policy that promotes macroeconomic stability with respect for the law and contracts, that stimulates competitiveness, and encourages private sector development or private investment, including FDI is required (Demekas et al., 2007).

Varsakelis et al. (2011) concluded that there are many other factors besides fiscal competitiveness (generated through lowering corporate income tax rates) that affect FDI decisions. They argued that small economies (small players) are not able to compete through only taxes to capture FDI from large economies. Any nation or state that have no incentive, for instance Portugal, Spain, and Greece may have difficulties in attracting Foreign Direct Investment while those nations with incentives may have other significant factors other than lower tax rates. According to Jeffrey Owens, Director of the Global Tax Policy Centre at the Institute for Austrian and International Tax Law, unattractive fiscal regimes are able to attract FDI because the tax is just one of the factors to take into account in the investment decision process and any company that allows only tax to drive its business will not be around for very long ( Gilleard, 2013, p. 21). Haufler \& Runkel (2008) claimed that fiscal rules that are designed specifically to attract foreign capital are more important in affecting FDI decisions than fiscal policies changing statutory tax rates. In the same line as specific tax rules on thin capitalization affecting FDI decisions, Beuttner et al (2008) concluded that restrictions on tax deduction of interest, resulting from changes to fiscal rules on thin capitalization, have a negative impact on capturing FDI. Stowhase (2003b) concluded in this connection that FDI in different sectors respond with different levels of elasticity to the fiscal incentives of the host country and that the FDI made with different objectives will respond differently to the different types of fiscal incentives, that is, rules that allow rapid fiscal depreciation can be relevant for a certain type of FDI but irrelevant for another.

Lastly, with respect to the existence of studies arriving at opposing conclusion, the research on this subject does not allow clear conclusions to be drawn. Despite many authors claim that there is a relationship between the tax rate and FDI, others conclude that the effect of the tax rate is not significant in their decisions; and even among authors who defend the existence of a significant influence of the tax rate on FDI decisions, there is no agreement regarding the degree of influence. It is in this context that the importance of fiscal policies in FDI decisions should be assessed, knowing that, on one hand, there are attractiveness factors that are important explanatory variables in FDI decisions, and on the other, fiscal policy is only one of various policies in host countries likely to influence FDI decisions.

Based on those studies, this research paper would attempt to bridge the gap in the field of study by examining the corporate tax as a competitive advantage on foreign direct investment inflow in Ireland and other selected nations in European Union. Second, we will determine whether corporate tax would be a decisive factor that would influence multinational firms to invest abroad versus home country.

\subsection{Methodology}

The secondary data for foreign direct investment (FDI) inflows as a percentage of Gross Domestic Product (GDP) 
will be obtained from United Nations Conference on Trade and Development (UNCTAD). The independent variables (corporate tax rate, inflation, labor force, and trade openness) will be retrieved from World Bank and Organization for Economic Co-operation and Development (OECD). All these sources are verified and valid.

The study used quantitative analysis; Panel Least Square regression will be employed as an econometric approach. Annual data for the dependent variable (FDI as a percentage of GDP) and independent variables (corporate tax rate, inflation rate, and labor force) of Ireland for a 28 years period from 1990-2017. The empirical analysis will be used to examining the relationship among FDI as a percentage of GDP, corporate tax as a proxy of fiscal policy, and other factors that may influence the location of foreign direct investment.

\section{Model Specification}

In this research, we will use the panel regression model with ordinary least square method to access the potential significance of corporate tax and related factors on foreign direct investment as a competitive advantage in Ireland economies. Panel regression allows controlling both for panel unit effect and for time effect when estimating regression coefficients. Also, it is used to know the extent certain independent variables explain variation in a dependent variable of interest as well as interactions among multiple independent variables and a dependent. $\widehat{\mathrm{FDI}}_{\mathrm{i}}=f(\mathrm{CTR}, \mathrm{INFR}, \mathrm{LF})$, the panel regression model is presented as:

where;

$$
\text { yit }=\mathrm{a}+\text { bxit }+ \text { cit }
$$

$\mathrm{y}$ is the dependent variable,

$\mathrm{x}$ is the independent variable,

$\mathrm{a}$ and $\mathrm{b}$ are coefficients, $\mathrm{i}$ and $\mathrm{t}$ are indices for individuals and time.

The error term is very important in this analysis. The error term speaks of fixed effects or random effects. However, we will use the multiple regression model with ordinary least square method to access the potential significance of corporate tax and related factors on foreign direct investment as a competitive advantage in Ireland economies. Multiple regression is used to analyze associations between two or more independent variables and a dependent variable. Also, it is used to know the extent certain independent variables explain variation in a dependent variable of interest as well as interactions among multiple independent variables and a dependent.

$\widehat{\mathrm{FDI}}_{\mathrm{i}}=f(\mathrm{CTR}, \mathrm{INFR}, \mathrm{LF}, \mathrm{TOP})$, the regression equation is presented as:

$\widehat{F D I} I_{i}=\hat{\beta}_{0}+\hat{\beta}_{1} C T R+\hat{\beta}_{2} I N F R_{i}+\hat{\beta}_{3} L F+\hat{\beta}_{4} T O P+e_{i}$

where $\widehat{F D} I_{i}-$ Foreign Direct Investment as percentage of GDP;

$\hat{\beta}_{0}-$ the intersection of the regression line

$\hat{\beta}_{1} C T R$ - Corporate tax rate of Ireland;

$\hat{\beta}_{2} I N F R$ - Inflation rate of Ireland;

$\hat{\beta}_{3} L F-$ Labor force of Ireland;

$\hat{\beta}_{4} T O P$ - Trade Openness of Ireland

$e_{i}$ - Error term.

\section{Hypotheses}

1. $\mathrm{H}_{0}$ : Corporate tax rate does not influence foreign direct investment in Ireland

$\mathrm{H}_{1}$ : Corporate tax rate does influence foreign direct investment in Ireland

2. $\mathrm{H}_{0}$ : Inflation rate not influence foreign direct investment in Ireland

$\mathrm{H}_{1}$ : Inflation rate does influence foreign direct investment in Ireland

3. $\mathrm{H}_{0}$ : Labor force does not influence foreign direct investment in Ireland

$\mathrm{H}_{1}$ : Labor force does influence foreign direct investment in Ireland

4. $\mathrm{H}_{0}$ : Trade Openness does not influence foreign direct investment in Ireland

$\mathrm{H}_{1}$ : Trade Openness does influence foreign direct investment in Ireland 


\subsection{Data Presentation and Discussion of Findings}

Table 1: Result of the Panel Least Square Regression Analysis

\begin{tabular}{|c|c|c|c|c|}
\hline \multicolumn{5}{|l|}{$\begin{array}{l}\text { Model: } \\
\widehat{F D} I_{\mathrm{i}}=f(\mathrm{CTR}, \mathrm{INF}, \mathrm{LFR}) \\
\text { Dependent variable: } \mathrm{FDI} \% \mathrm{GDP}\end{array}$} \\
\hline Independent Variables & Coefficient & Std. Error & t-Statistic & Prob. \\
\hline $\mathrm{C}$ & -41.32405 & 9.204834 & -4.489386 & 0.0000 \\
\hline CTR & 3.610721 & 1.034203 & 3.491306 & 0.0006 \\
\hline INF & -0.913763 & 0.470261 & -1.943097 & 0.0541 \\
\hline LFR & 0.696032 & 0.148168 & 4.697587 & 0.0000 \\
\hline & R-squares & $\begin{array}{l}\text { Adjusted } \\
\text { squared }\end{array}$ & $\begin{array}{l}\text { Durbin- } \\
\text { Warson stat }\end{array}$ & Prob.(F-statistic) \\
\hline & 0.214194 & 0.196860 & 0.801209 & 0.0000 \\
\hline
\end{tabular}

\section{Source: EViews}

Table 1 shows the result from the panel regression model where Foreign Direct Investment as per \% Gross Domestic Product (FDI\%GDP) is the dependent variable. All three independent variables Corporate Tax rate and labor force rate have a positive correlation while inflation rate has a negative correlation with FDI. Corporate tax rate and labor force variables are statistically significant at $p<0.05$. Inflation rate is not significantly significant as $\mathrm{p}>$.05. An increase in Labor force will lead to an increase in FDI. Also, when the inflation rate reduces the foreign direct investment will increase. The predicting power of the model reveals that the three independent variables used in the study can explain the variation in FDI\%GDP up to 20\%. The Adjusted R-squared considers the number of independent variables used for predicting the target variables. For this model, we reject the null hypothesis for Corporate tax rate, labor force rate and inflation rate because these independent variables have a significant influence on FDI\%GDP.

This result is consistent with previous studies that have examined the impact of Corporate tax rate in determinant of FDI location. Early studies of Hines (1999) found that a reduced tax burden affects the level of FDI. Gropp (2000) discovers a link between taxation and FDI and suggested that changes in the tax rate have generated a significant impact on investment decisions especially in Organization for Economic Co-operation and Development (OECD) countries. He argued that the low tax rate in Ireland contributed decisively to the country's success in attracting FDI. However, the study of Varsakelis et al. (2011) concluded that there are many other factors that affect foreign direct investment in a nation besides lowering corporate tax rate an example of this was shown in the Table 1 above where labor force and inflation rate indicate a significant impact on the foreign direct investment of Ireland as a nation. The results above indicte that countries exercising a lower corporate tax rate are likely to attract greater foreign direct investment compared to surrounding regions if other economic indicators such as labor force are at similar levels. In conclusion, of the EU countries considered in the panel regression, corporate tax rate shows to be a significant variable of influence over the inflow of foreign direct investment.

Table 2: Result of the Multiple Regression Analysis

\begin{tabular}{|l|l|l|l|l|}
\hline $\begin{array}{l}\text { Model: } \\
\widehat{F D I}_{\mathrm{i}}=f(\mathrm{CTR}, \mathrm{INF}, \mathrm{LFR}, \mathrm{TOP}) \\
\text { Dependent variable: FDI\%GDP }\end{array}$ & & & & \\
\hline Independent Variables & Coefficient & Std. Error & t-Statistic & Prob. \\
\hline C & -47.32877 & 50.79636 & -0.931735 & 0.3612 \\
\hline CTR & -1.794236 & 5.296582 & -0.338754 & 0.7379 \\
\hline INF & -0.359346 & 1.475573 & -0.243530 & 0.8098 \\
\hline LFR & 0.242680 & 1.043721 & 0.232515 & 0.8182 \\
\hline TOP & 0.337759 & 0.105478 & 3.202187 & 0.0040 \\
\hline & & & & \\
\hline & & $\begin{array}{l}\text { Adjusted R- } \\
\text { squared }\end{array}$ & $\begin{array}{l}\text { Durbin- } \\
\text { Warson stat }\end{array}$ & Prob.(F-statistic) \\
\hline & R-squares & 0.4226 & 1.8613 & 0.0019 \\
\hline
\end{tabular}

Source: EViews

Table 2 shows the result from the regression model where Foreign Direct Investment as per \% Gross Domestic Product (FDI\%GDP) is the dependent variable. All four independent variables - Corporate Tax rate and Inflation have a negative correlation while Labor force rate and Trade Openness have a positive correlation with FDI. Trade Openness was statistically significant at $\mathrm{p}<0.05$. An increase in Labor force and Trade Openness will lead to an increase in FDI. Also, the predicting power of the model reveals that the four independent variables used in the study can explain the variation in FDI\%GDP up to 50\%. For this model, we reject the null hypothesis for Trade 
Openness because it has a significant impact on FDI\%GDP. The three other independent variables (Corporate tax rate, Inflation, Labor force rate) have no significant influence on FDI\%GDP. Therefore, we fail to reject null hypothesis because we do not have enough evidence.

This result is consistent with previous studies that have examined the impact of Corporate tax rate in determinant of FDI location. Early studies from Jun (1994) and Cassou (1997) indicated that corporate tax does not have a significant impact on FDI. However, the study of Varsakelis et al. (2011) concluded that there are many other factors that affect foreign direct investment in a nation besides lowering corporate tax rate an example of this was shown in the Table 1 above where trade Openness indicates a significant impact on the foreign direct investment of Ireland as a nation.

The result above further proved that nations may not have tax incentive or lower tax rate and will attract foreign direct investment if the economy environment is friendly for foreign investors. According to Liargovas \& Skandalis (2012) found that trade openness contributes positively to the inflow of FDI. Ashgar (2016) examined the relationship between FDI inflows and trade openness in South-Asian economies. He examined the relationship of seven countries for the 1998-2010 period based on panel data using random effects estimation. Trade openness was measured by three indicators, in terms of imports, exports and a joint combination of both factors. His results suggested that there is a significant relationship between trade openness and foreign direct investment inflows. Trade openness has a positive and significant impact on FDI inflows in South-Asian countries.

\subsection{Conclusion, Recommendations and Future Research}

In this paper, we have sought to investigate the influence of fiscal policy on foreign direct investment inflow (FDI): A case of Ireland. We discovered that the relationship between fiscal policy and FDI is significant. We conclude that there is empirical evidence that exogenous variables such as labor force and inflation rate are more influential for attracting FDI. However, fiscal policies affect the investment decision more directly when other policies of the potential countries considered for investment are convergent. Potential obstacles of this study include external environmental influences that act as disruptions that pose a psychological effect on the levels of FDI inflow to host nation or spent by MNEs. The practical implication of this study is to understand conditions and the relationship between corporate tax rates and other determinants have for host countries who wish to attract foreign direct investments. These conditions would create a healthy business environment for sustainable growth for both the investing MNEs and host nations.

The study recommends that firms seek financial gain through corporate tax rates as a leading determinant and aim to identify how corporate tax rates contrast in FDI levels between countries within the EU acknowledge that other factors that can create a healthy business environment for sustainable growth for both in the investing MNEs and host nations are important. Future research can investigate government spending as a tool of fiscal policy in relation to foreign direct investment in the same country.

\section{References}

Alan, A., \& Estrin, S. (2000). The Determinants of Foreign Direct Investment in Transition Economies. William Institute Working Paper, 342.

Asghar, A. (2016). Foreign Direct Investment and Trade Openness: the Case of South Asian Economies. International journal of Innovation and Applied Studies, 17(2), 513-517.

Benassy, A., Fontagne, L., \& Lahreche, A. (2003). Tax Competition and Foreign Direct Investment. CEPII Working Paper, 2003-2017.

Benassy-Quere, A., Fontagne, L., \& Lahreche, A. (2000). Foreign Direct Investment and the Prospectus for Tax Coordination in Europe. CEPII Working Paper, 2000-2006.

Bennassy-Quere, A., Fontagne, L., \& Lahreche, A. (2005). How does Foreign Direct Investment react to Corporate Taxation? International Law and Public Fincance, 583-603.

Beuttner, T., Overesch, M., Schreiber, U., \& Wamser, G. (2008). The Impact of Thin Capitalization rules on Multinational's FInancing and Investment Decisions. Frankfurt: Deutsche Bundesbank Discussion Paper.

Bevan, A., \& Estrin, S. (2000). The Determinants of Foreign Direct Investment in Transition Economies. Center for Economic Policy Research, 2638.

Boskin, M., \& Gale, W. (1987). New Results on the effects of tax policy on the international location of investment. Chicago: University of Chicago Press.

Carstensen, K., \& Toubal, F. (2004). Foreign direct Investment in central and eastern European Countries: A dynamic Panel Analysis. Journal of comparative economics, 3-22.

Cassou, S. P. (1997). The Link between Tax rates and Foreign Direct Investments. Applied Economics , $1295-$ 1301.

Cummins, J., \& Hubbard, R. (1995). The Tax sensitivity of foreign direct investment: Evidence from firm level panel Data. The effects of taxation on multinational corporations. Chicago: University of Chicago Press.

Demekas, D., Horvath, B., Ribacova, E., \& Wu, Y. (2007). Foreign Direct Investments in European transition 
Economies: The role of policy. Journal of Comparative Economics, 369-386.

Desai, M., \& Hines, J. (2001). Foreign Direct Investment in a world of multiple taxes. National Bureau of Economic Research, 8440.

Desai, M., Foley, C., \& Hines, J. (2002). Chains of Ownership, Regional tax competition and foreign direct Investment. National Bureau of Economic Research, 9224.

Devereux, M., \& Freeman, H. (1995). The Impact of Tax on foreign direct investment: Empirical evidence and the implications for tax integration schemes. International tax and public Finance, 85-106.

Diamond, P., \& Mirrlees, J. (1971). Optimal taxation and Public Production. American Economic Review, 261278.

Dunning. (2000). The Impact of FDI on developed Nations. Economic Journal, 1-10.

Gilleard, M. (2013). BRICS attracting investment despite their tax system. International Tax Review.

Gondor, M., \& Nistor, P. (2012). Fiscal Policy and Foreign Direct Investment: Evidence from some Emerging EU Economies. Procedia: Social and Behavioral Sciences, 1256-1266.

Gondor, M., \& Nistor, P. (2012). How does FDI React to Fiscal Policy? The Case of Romania. Procedia Economics and FInance, 629-634.

Gropp, R., \& Kostial, K. (2000). The disappearing tax base: Is foreign direct investment eroding corporate income taxes? International Monetary Fund Working Paper, 173.

Grubert, H., \& Mutti, J. (2000). Do taxes influence where US Corporations Invest? National Tax Journal, 825839.

Hartman, D. (1984). Tax Policy and Foreign Direct Investment in United States. National Tax Journal, 1087-1103.

Haufler, A., \& Runkel, M. (2008). Firms' Financial choices and thin capitalization rules under tax competition. eUROPEAN ECONOMIC rEVIEW, 1087-1103.

Hines, J. (1999). Lessons from Bahavioral Responses to International Taxation. National Tax Journal, 305-322.

Janicki, H., \& Wunnava, P. (2004). Determinants of foreign Direct Investment: Empirical Evidence from EU accession Candidates. Applied Economics, 505-509.

Jun, J. (1994). How Taxation affects foreign direct investment (country-specific). Policy Research Working Paper, 1307.

Krautheim, S., \& Schmidt, T. (2011). Heterogeneous Firms, 'Profit Shifting' FDI and Tax Competition. Journal of Public Economics, 122-133

Lankes, H., \& Venables, A. (1996). Foreign economic investment in economic transition: the changing pattern of investments. Economics of Transition, 331-347.

Liargovas, P. S. (2012). Foreign Direct Investment and Trade Openness: The Case of Developing Economies. Social Indicators Research, 106, pages323-331.

Lucas, R. (1993). On the determinants of Foreign Direct Investment: Evidence from East and Southeast Asia. World Development, 391-406.

Mitchell, D. (2008). The Economics of Tax Competition: Harmonization vs Liberalization. Adam Smith Institute (pp. https://static1.squarespace.com/static/56eddde762cd9413e151ac92/t/5ae9ba8970a6ad102dc12433/1525267 090079/tax-competition.pdf.

Neruda, D. (2008). Tax Harmonization in the EU. Acta Universities, 139.

Pain, N., \& Young, G. (1996). Tax Competition and the pattern of European foreign direct investment. Mimeo National Institute of Economic and Social Reasearch.

Razin, A., \& Sadka, E. (2006). Vying for Foreign Direct Investment: The EU tax model of tax competition. NEBER working Paper.

Slemrod, J. (1990). Tax Effects on Foreign Direct Investment in the United States: Evidence from a cross country comparison. University of Chicago Press, 79-117.

Swenson, D. (1994). The impact of United States Tax Reform on Foreign Direct Investment in the United States. Journal of Public Economics, 243-266.

Veugelers, R. (1991). Locational Determinanct and Ranking of Host Countries: An Empirical Assessment. KYKLOS International Review for Social Sciences, 363-382.

Young, K. (1988). The effects of taxes and rates of return on foreign direct investment in the United States. National Tax Journal, 109-121. 